\title{
RISK ASSESSMENT USING EXPANDED POINT METHOD IN CIVIL ENGINEERING
}

\author{
Miroslav ŽITŇÁK*, Katarína KOLLÁROVÁ, Jana LENDELOVÁ, Lukáš DOLEJŠ \\ Slovak University of Agriculture in Nitra, Slovak Republic
}

\begin{abstract}
Nowadays, there are increasing discussions concerning an extensive area of occupational safety and health, whether is it within the territory of the Slovak Republic or in other Member States of the European Union. Every organization prepares independently its own policy of occupational safety and health using applicable legislation. The objective of this work was to minimize the errors resulting not only from the human factor but also from incorrect working procedures, from failing to observe legal requirements, and from an incorrect use of personal protective equipment. After evaluating the risk level in working activities of employees on site, we have proposed measures to reduce the risk by means of defining correct working procedures and using personal protective equipment. That enables reducing occupational injuries, which will directly improve the overall level of occupational safety and health on a selected site.
\end{abstract}

Keywords: risk, civil works, occupational safety

To achieve an acceptable level of safety, it is necessary to create the policy of occupational safety and health $(\mathrm{OSH})$ (Korenková, 2008) and to determine the objectives and procedures of its implementation within a company (Bujna et al., 2011). However, the awareness of OSH must be further built in all employees (Višňovský and Korenková, 2004; Korenková, 2012); this procedure is performed from the top management, through all levels, up to employees (Feszterová, 2013). Also a good mutual communication between employers and employees as well as their motivation to safe work in company is important, which significantly contributes to the level of corporate culture (Hulínová, 2005). The highest priority of improving the human performance is in avoiding human errors during working activities (Korenko et al., 2010; Korenko et al., 2010). In every working activity, it is important to correctly define and analyze all errors that may occur with these activities, even if only theoretically (Korenko, 2012). The assessment of risks forms a basis of every approach to managing $\mathrm{OSH}$ and is a core element when establishing a sound workplace (Pačaiová et al., 2009). The strategy of the European Community in the field of OSH for the time period of 2007 - 2012 recognizes the importance of assessing risks and calls for creating simple tools that would simplify the process of assessing risks. The objective of this work was to minimize the errors resulting not only from the human factor but also from incorrect working procedures, from failing to observe legal requirements, and from an incorrect use of personal protective equipment (PPE).

\section{Material and methods}

The subject of our examination is assessing the achieved level of OSH in civil works. We have focused on determined objectives of the selected building company in the field of $\mathrm{OSH}$ and assessed their level of fulfilment during the construction of a specific building.

We proceeded according to the following methodology:
- collecting documents concerning the building safety documentation,

- determining the schedule and performing checks in cooperation with a site manager,

- selecting a suitable method for assessing risks on site,

- identifying risks using an expanded point method,

- proposal of safety measures to reduce the risk identified.

When assessing the risk, we have used the 'extended point method', which belongs to the most frequently used methods in the field of assessing risks. The greatest benefit of this method is the process of assessing and evaluating risks, which is fast and effective thanks to point evaluation. This assessment was performed having regard to all work-related circumstances so that the workplace, machines, equipment, implements, tools, materials, working procedures, working aids, the layout of working places, and the organization of work do not endanger the safety and health of employees. Assessment included all employees and other persons that could be exposed to risk. The assessment of risk that could arise at work was determined by visual inspection and was evaluated using the above-mentioned point method by which the risk rate was determined and safety measures were proposed. Identified shortcomings were documented graphically. Persons involved were informed of risks resulting from their working activities.

\section{Risk assessment using expanded point method}

Risk is a mutual relationship between the probability of occurrence of a negative phenomenon and its consequence. Risk assessment was performed using the expanded point method, within the meaning of definition:

$$
R=P \cdot D \cdot V
$$

where:

$P \quad$ - probability of occurrence of a given event (Table 1)

$D$ - consequence of the monitored event (Table 2)

$V$ - opinion of assessors (Table 3)

$R \quad$ - risk rate (Table 4) 
Table 1 Probability of event incidence

\begin{tabular}{|l||l|}
\hline Value & Defining the event incidence in terms of probability \\
\hline \hline $\mathbf{1}$ & Improbable - undesirable event is almost eliminated \\
\hline $\mathbf{2}$ & $\begin{array}{l}\text { Random - undesirable event is hardly probable, but } \\
\text { possible }\end{array}$ \\
\hline $\mathbf{3}$ & Probable - undesirable event could occur \\
\hline $\mathbf{4}$ & Very probable - undesirable event will probably occur \\
\hline $\mathbf{5}$ & $\begin{array}{l}\text { Permanent - undesirable event will occur very } \\
\text { frequently }\end{array}$ \\
\hline
\end{tabular}

Table $\mathbf{2}$
\begin{tabular}{|l||l|}
\hline Value & \multicolumn{1}{c|}{ Consequence of event occurred } \\
\hline \hline $\mathbf{1}$ & $\begin{array}{l}\text { Negligible - small injury - less than light injury, } \\
\text { negligible financial and material losses }\end{array}$ \\
\hline $\mathbf{2}$ & $\begin{array}{l}\text { Least significant - light injury, disease, beginning of } \\
\text { occupational disease, low financial and material losses }\end{array}$ \\
\hline $\mathbf{3}$ & $\begin{array}{l}\text { Significant - a more severe injury requiring } \\
\text { hospitalization, higher financial and material losses }\end{array}$ \\
\hline $\mathbf{4}$ & $\begin{array}{l}\text { Critical - severe injury with permanent consequences, } \\
\text { occupational disease, high financial and material } \\
\text { losses }\end{array}$ \\
\hline $\mathbf{5}$ & $\begin{array}{l}\text { Catastrophic - fatal, mass accident, irretrievable losses, } \\
\text { losses leading to liquidation }\end{array}$ \\
\hline
\end{tabular}

Table 3 Opinion of assessors

\begin{tabular}{|l||l|}
\hline Value & $\begin{array}{c}\text { Defining the importance of effect on probability } \\
\text { and consequences }\end{array}$ \\
\hline \hline $\mathbf{1}$ & $\begin{array}{l}\text { Negligible effect on probability and consequences } \\
\mathbf{2}\end{array}$ \\
\hline $\mathbf{3}$ & $\begin{array}{l}\text { Least significant effect on probability and } \\
\text { consequences }\end{array}$ \\
\hline $\mathbf{4}$ & $\begin{array}{l}\text { Significant, high effect on probability and } \\
\text { consequences }\end{array}$ \\
\hline $\mathbf{5}$ & $\begin{array}{l}\text { Several significant effects on probability and } \\
\text { consequences }\end{array}$ \\
\hline
\end{tabular}

Table $\mathbf{4}$
\begin{tabular}{|l||l|}
\hline Value & \multicolumn{1}{c|}{ Defining the risk rate } \\
\hline \hline $\mathbf{1 - 4}$ & Negligible - acceptable safety \\
\hline $\mathbf{5 - 1 0}$ & $\begin{array}{l}\text { Moderate - acceptable risk at increased } \\
\text { attention }\end{array}$ \\
\hline $\mathbf{1 1 - 5 0}$ & $\begin{array}{l}\text { Serious - risk cannot be accepted without } \\
\text { protective measures }\end{array}$ \\
\hline $\mathbf{5 1 - 1 0 0}$ & $\begin{array}{l}\text { Undesirable - insufficient safety, high risk of } \\
\text { accidents and undesirable events }\end{array}$ \\
\hline $\mathbf{1 0 1 - 1 2 5}$ & $\begin{array}{l}\text { Inacceptable - permanent threat of accident, } \\
\text { irretrievable losses }\end{array}$ \\
\hline
\end{tabular}

\section{Results and discussion}

Inspections in the field of $\mathrm{OSH}$ were performed in cooperation with a safety coordinator - in this case, an authorized safety officer who is competent for performing inspections of meeting OSH. Regularly performed inspections focused on meeting the legal regulations and directives for performing works on site. During inspections, we verified whether workers were acquainted with risks arising with certain activities on site. Identified shortcomings were documented by preparing graphical records (photographs) that were subsequently evaluated using the expanded point method. After evaluating the risk rate that influences workers, we proposed safety measures to reduce the risk. Identified shortcomings, risk rate and proposed safety measures were communicated to managers and persons executing given works. Graphical records of performed inspections and determined values of risks are recorded in the building safety documentation. Risk evaluation and its correct documentation are of high importance for the subsequent determination of meeting the established objectives and safety level in the given company. Identified shortcomings:

- As shown in Figure 1, the worker in height is not secured against fall.

- The workers below the workplace in height do not use personal protective equipment to protect their heads; a similar risk evaluation is shown in Table 5.
Proposed measures:

- The worker at the border of workplace in height must be secured at least by a safety belt with a jumper anchored to a fixed structure.

- PPE must unconditionally be used in height to protect the head.

- Enclosing the space and avoiding the access of persons below the workplace in height.

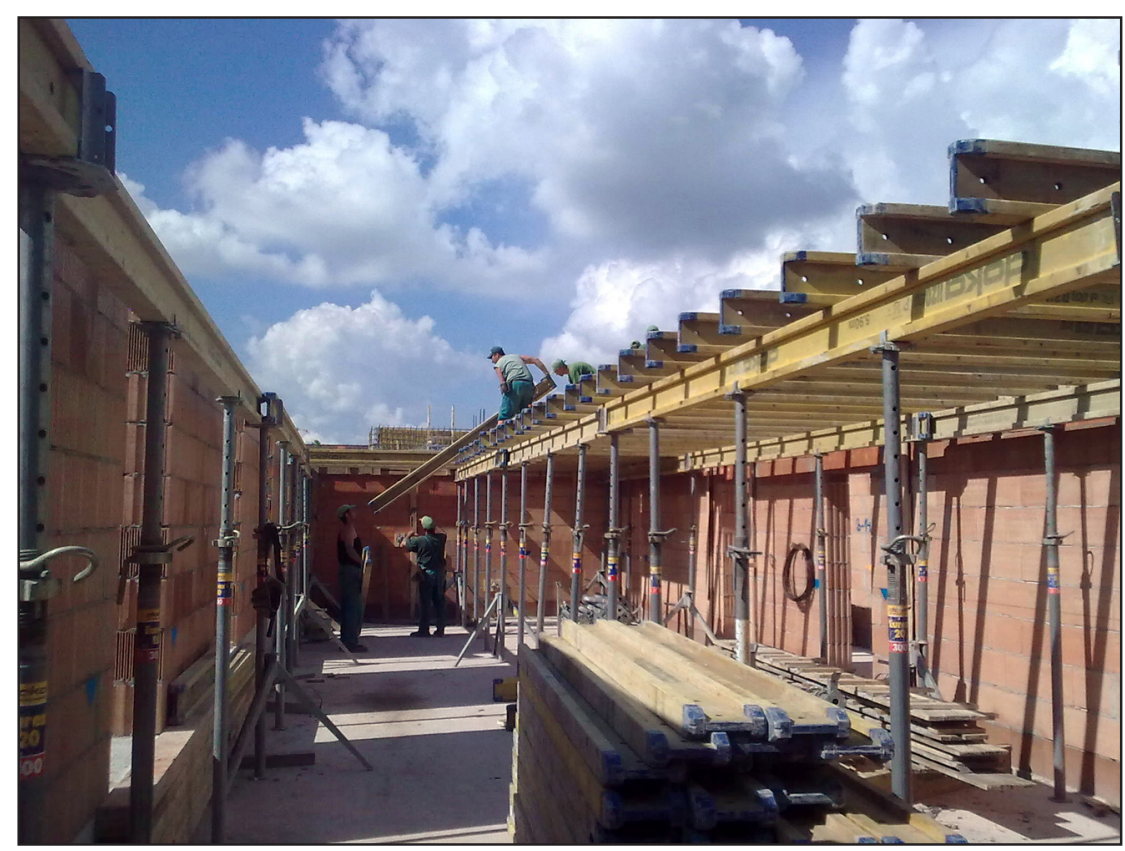

Figure 1

Assembling the formwork of Doka system type for horizontal structures 

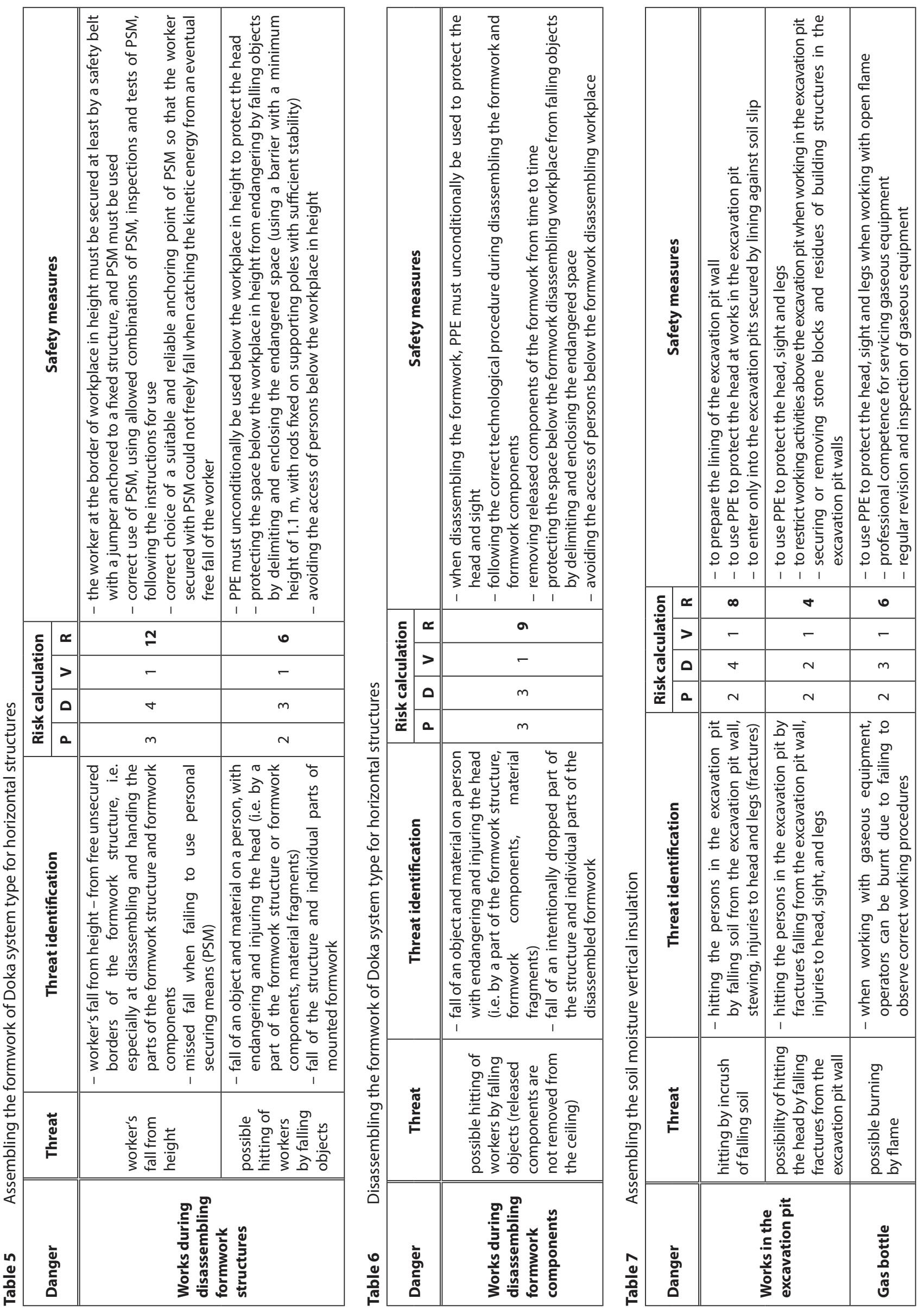


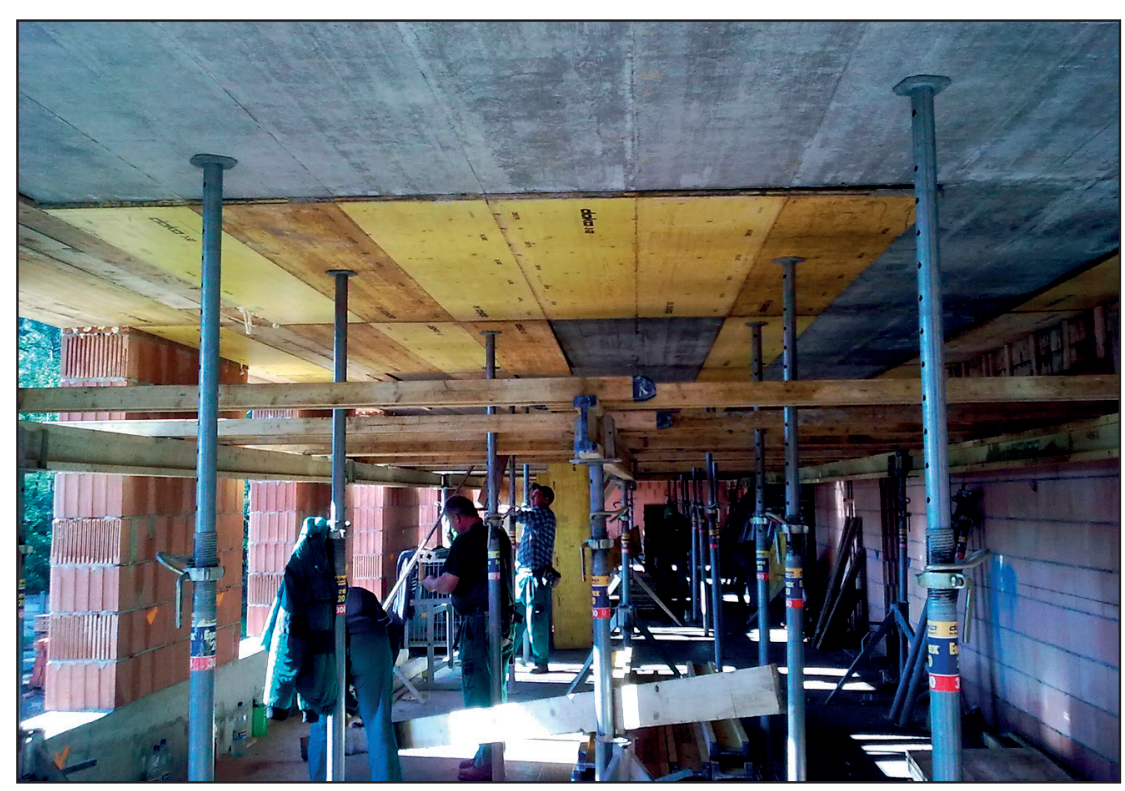

Figure 2 Disassembling the formwork of Doka system type for horizontal structures

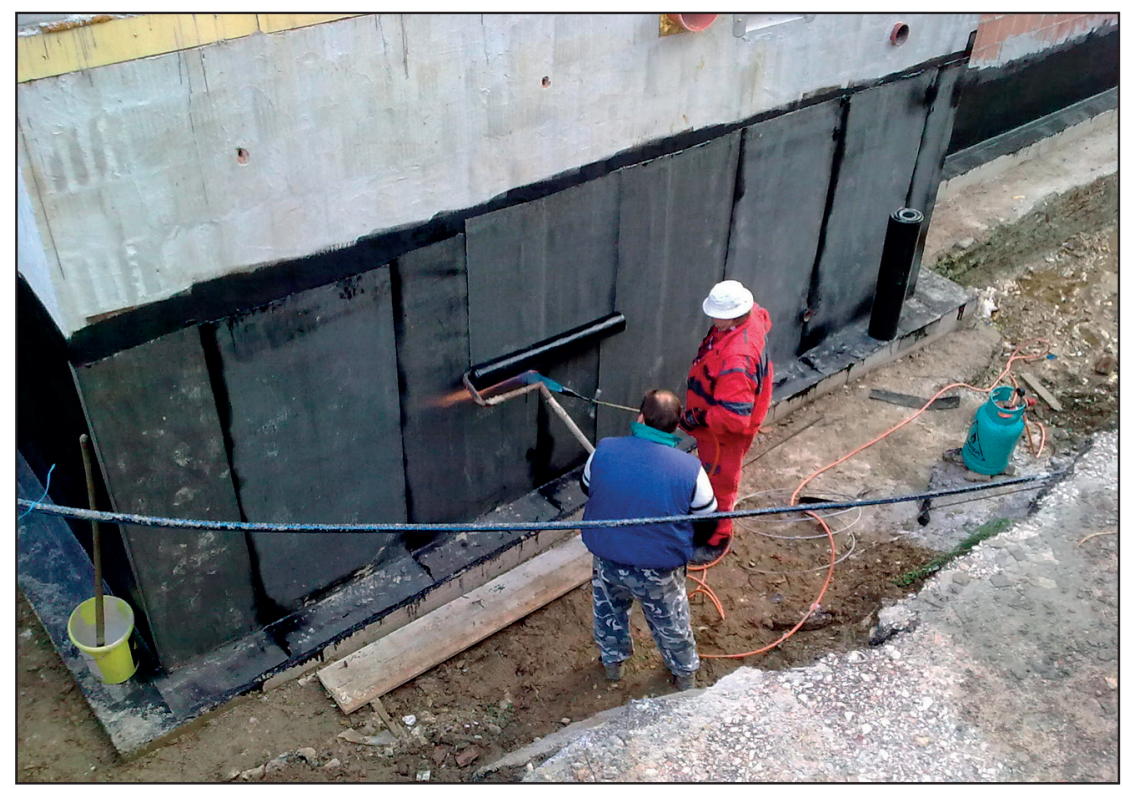

Figure 3 Assembling the soil moisture vertical insulation

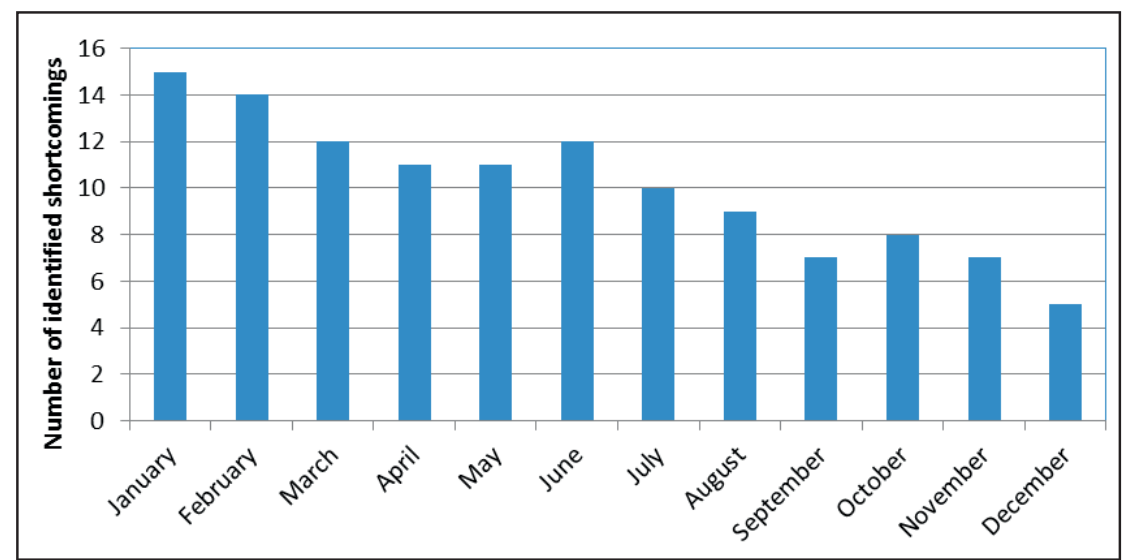

Figure 4 Number of identified shortcomings in year 2010
Identified shortcomings:

- Figure 2 illustrates that the workers do not use PPE at work to protect the head and sight, whereby there is a high probability that the disassembled material will fall; a detailed risk assessment is shown in Table 6.

Threat:

- Hitting a worker (especially the head) by a falling object.

- Released components of the disassembled formwork are not removed from the ceiling.

Proposed measures:

- Using PPE to protect the head and sight.

- Following the correct technological procedure when the formwork is disassembled.

- Removing released formwork components from time to time.

Identified shortcomings:

- As can be seen in Figure 3, the workers do not use PPE to protect their heads near the excavation pit wall.

- Unsecured excavation pit stability; the detailed assessment of the resulting risk can be seen in Table 7 .

Proposed measures:

- Preparing the lining of the excavation pit wall.

- Using PPE to protect the head when working in the excavation pit.

- Securing or removing stone blocks and residues of building structures in the excavation pit walls.

- Professional competence for servicing gaseous equipment.

All building companies should remember that every site as well as conditions of given premises and their surroundings is unique and unrepeatable. Therefore, it is clear that the plan of OSH as well as the assessment of risks cannot be elaborated schematically, but must be tailored to a given situation, conditions of a given site, and mutual relationships.

\section{Evaluation of meeting $\mathrm{OSH}$ during block of flats construction}

During the construction of a block of flats, the persons who performed works on this building were informed about identified shortcomings and the risk resulting from them. Furthermore, these workers were 
instructed in proposed correcting measures. During subsequent inspections of meeting OSH, the degree to which the proposed measures to reduce risks were met was also verified. Identified shortcomings were documented, recorded, and evaluated graphically.

Figure 4 illustrates the evaluation of shortcomings identified during inspection of meeting OSH for individual months of year 2010. However, it should be noted that several sub-contractors took part in the construction of the building during the inspection of meeting $\mathrm{OSH}$, and works were performed according to the schedule of works with respect to technological procedures. That directly influenced the volume of performed works and the number of workers on site during one month, and subsequently, also the number of identified shortcomings in the given month.

\section{Conclusion}

When assessing risks, it is necessary to care especially about the safety of workers who should be familiar with their own occupational health and safety. When performing their works, they should be very particular primarily about their safety, use suitable protective equipment, meet prescribed working procedures, and should not consider OSH as a burden but as the protection of their health at work. However the company may strive to ensure a safe working environment for its employees, it will be vain if every employee alone does not realize that they must observe determined regulations they were instructed in, and so they will reduce the rate of risks they are put at.

It is necessary to constantly and regularly perform checks of the state and meeting of OSH. It is important to identify how and why employees fail to meet, or even violate safety regulations. In order to prevent from any unnecessary accidents and occupational diseases, OSH should also be checked randomly.

\section{References}

BUJNA, M. - PRÍSTAVKA, M. - KORENKO, M. 2011. Analýza ohrozenia metódou FMEA. In Kvalita a spolahlivost' technických systémov. Nitra : SUA, 2011. pp. 257-261.

FESZTEROVÁ, M. 2013. Dodržiavanie zásad bezpečnej práce. Nitra : Constantine the Philosopher University, 2013.

HULínOVÁ, Z. 2005. Bezpečnost' a ochrana zdravia pri práci v stavebníctve. Bratislava : SUT, 2005.

KORENKO, M. 2012. Manažérstvo kvality procesov. Nitra : SUA, 2012. KORENKO, M. - KAPLÍK, P. - BULGAKOV, V. 2010. Implementation of $5 \mathrm{~S}$ approach in the manufacturing organization. In Naukovij Visnik Nacionalnogo Universitetu Bioresursiv i Prirodokoristuvanja Ukrajiny. Kijiv : Nacional'nyj Univesitet Bioresurstv Prirodokoritsuvanja Ukrajiny, 2010. pp. 59-64.

KORENKO, M. - KAPLÍK, P. - JABLONICKÝ, J. - BULGAKOV, V. 2010. Detection of reserve production organizations by raising the performance of their production processes. In Mechanizacija ta Elektrifikacija Sil'skogo Gospodarstva, vol. 94, 2010, no. 1, pp. 518-524.

KORENKOVÁ, M. 2008. Podnikanie a manažment. Nitra: Constantine the Philosopher University, 2008.

KORENKOVÁ, M. 2012. Approaches of managers to solving the conflicts at workplace. In Journal on Law, Economy and Management, vol. 2, 2012, no. 2, pp. 56-60.

PAČAIOVÁ, H. - SINAY, J. - GLATZ, J. 2009. Bezpečnost’ a riziká technických systémov. Košice: TU, 2009.

VIŠŇOVSKÝ, J. - KORENKOVÁ, M. 2004. Possible approaches to the solution of conflict situation in managerial practice. In Agricultural Economics, vol. 50, 2004, pp. 342-344.

\section{Contact address:}

Miroslav Žitňák, Slovak University of Agriculture in Nitra, Faculty of Engineering, Department of Structures, Tr. Andreja Hlinku 2, 94976 Nitra, Slovak Republic, e-mail: miroslav. zitnak@uniag.sk 